В.В. Коваль

Генеральний штаб Збройних Сил України, Київ

\title{
УДОСКОНАЛЕНА СУКУПНІСТЬ ПРИНЦИПІВ ЗАСТОСУВАННЯ СИЛ I ЗАСОБІВ МАСКУВАННЯ ВІЙСЬКОВИХ ОБ'ЄКТІВ ВІД ТЕХНІЧНИХ ЗАСОБІВ ПОВІТРЯНОЇ РОЗВІДКИ ТА НАВЕДЕННЯ ЗБРОЇ ПРОТИВНИКА
}

Зростання можливостей сучасних технічних засобів повітряної розвідки та наведення зброї (ТЗПРНЗ), нові форми та способи дій повітряного противника обумовлюють необхідність суттєвого підвищення ефективності проведення заходів маскування військових об'єктів. В статті, з урахуванням особливостей застосування ТЗПРНЗ в сучасних операџіях (бойових діях) визначено сукупність принципів застосування сил $і$ засобів маскування військових об'єктів, яка трунтується на базових приниипах маскування, вимогах до застосування сил $і$ засобів маскування в операчіях (бойових діях) та додатково враховує приниипи мінімальної достатності та інтероперабельності.

Ключові слова: технічні засоби повітряної розвідки та наведення зброї, маскування, принщипи.

\section{Вступ}

Постановка проблеми. Постановка завдання у загальному вигляді та його зв'язок із практичними заходами. У сучасних умовах ведення збройної боротьби особливого значення набувають заходи маскування військових об'єктів від технічних засобів повітряної розвідки та наведення зброї (ТЗПРНЗ) противника. Це обумовлено, насамперед, зростанням можливостей ТЗПРНЗ Збройних сил Російської Федерації щодо виявлення військових об'єктів для застосування противником високоточної зброї та різноманітних розвідувально-ударних (розвідувально-вогневих) комплексів та контурів (систем) [1-2]. За таких умов, виникає нагальна потреба ефективно проводити заходи маскування військових об'єктів від ТЗПРНЗ противника. При цьому, подальший розвиток теорії маскування військових об'єктів від ТЗПРНЗ противника, особливо застосовування сил і засобів маскування військових об'єктів від ТЗПРНЗ противника, неможливі без формулювання відповідних принципів, що і обумовлює актуальність даної статті.

Аналіз останніх досліджень і публікацій. Питанням застосування сил і засобів маскування військових об'єктів від ТЗПРНЗ противника присвячена низка наукових робіт [2-5]. У вказаних роботах розкриваються тільки принципи застосування окремих сил і засобів маскування (застосування димових підрозділів та аерозольних засобів, підрозділів інженерних військ та засобів маскування, тощо) або загальні принципи організації маскування військ та об'єктів. Проте, принципи комплексного (сумісного) застосування сил і засобів маскування військових об'єктів від ТЗПРНЗ противника розкритті недостатньо. Особливості дій повітряного противника, вимоги до застосування сил і засобів маскування військових об'єктів від ТЗПРНЗ противника в операціях (бойових діях) висвітлено недостатньо повно.

Тому метою статті $\epsilon$ формування удосконаленої сукупності принципів застосування сил і засобів маскування військових об'єктів від ТЗПРНЗ противника.

\section{Виклад основного матеріалу}

Результати проведеного аналізу положень керівних документів, теоретичних праць 3 організації маскування свідчать про необхідність дотримання під час застосовування сил і засобів маскування військових об'єктів від ТЗПРНЗ противника таких базових принципів маскування: активність, переконливість, безперервність, різноманітність та комплексність [47]. При цьому, кожен з цих принципів забезпечується таким чином:

- активність маскування від ТЗПРНЗ противника - наполегливим нав'язуванням противнику хибної уяви про наміри командування, стану, розташування й діяльності військ (сил) та військових об'єктів;

- переконливість маскування від ТЗПРНЗ противника - наполегливим нав'язуванням правдоподібності заходів і відповідності ї умов обстановки 3 урахуванням можливостей усіх видів розвідки противника, у тому числі ТЗПРНЗ;

- безперервність маскування від ТЗПРНЗ противника - постійним систематичним проведенням заходів маскування незалежно від умов обстановки та етапу операції (бойових дій); 
- різноманітність маскування від ТЗПРНЗ противника - виключенням шаблону в організації та здійсненні заходів маскування, а також застосуванням нових способів, прийомів та засобів маскування;

- комплексність маскування від ТЗПРНЗ противника - залученням до маскування військових об'єктів різнорідних сил і засобів, поєднанням різних способів (варіантів) маскування.

Результати аналізу локальних війн та збройних конфліктів сучасності [1-2], досвіду застосування Збройних Сил України на Сході нашої держави [35], дозволяють визначити основні особливості застосування ТЗПРНЗ в сучасних операціях (бойових діях):

- можливість ведення повітряної розвідки без перетину державного кордону (лінії бойового зіткнення) на всю глибину операційної зони, без входу в зони ураження засобів протиповітряної оборони, що дозволяє розкривати оперативну побудову військ та розташування військових об'єктів незалежно від місця їх розташування;

- значний радіус дій та швидкість польоту розвідувальних літальних апаратів, що дозволяє добувати необхідні дані про військові об'єкти в найкоротший термін;

- широкий діапазон робочих частот ТЗПРНЗ та можливість передачі розвідувальної інформації до користувачів в режимі часу, близькому до реального, що дозволяє створювати різноманітні за своїм складом та конфігурацією розвідувально-ударні (розвідувально-вогневі) комплекси та контури (системи);

- широкомасштабне застосування безпілотної авіації (розвідувальних “роїв” безпілотних апаратів) для підвищення достовірності ідентифікації цілей та визначення координат військових об'єктів, що дозволяє організовувати ведення розподіленої розвідки та нанесення сфокусованих точкових ударів.

Вказані особливості визначають основні вимоги до застосування сил і засобів маскування військових об'єктів від ТЗПРНЗ противника в операціях (бойових діях), а саме:

- доцільність - застосування сил і засобів маскування військових об'єктів від ТЗПРНЗ противника відповідно до загальної мети, завдань, характеру, форм і способів застосування військ (сил);

- відповідність - застосування сил і засобів маскування військових об'єктів від ТЗПРНЗ противника з урахуванням можливостей використання певного способу (варіанту) маскування на певному об'єкті на протязі заданого часу;

- пріоритетність - застосування сил і засобів маскування військових об'єктів від ТЗПРНЗ противника методом послідовного вибору об'єктів, виходячи із ступеня їх важливості у вирішенні стратегічних (оперативних) завдань військ (сил);

- гарантована протидія - застосування на військових об'єктах такої кількості сил і засобів маскування, які гарантовано протидіють ТЗПРНЗ противника;

- інтенсивність - виконання поставлених завдань маскування в терміни, що гарантують випередження застосування ТЗПРНЗ противника;

- достатність - застосування мінімальної кількості сил і засобів маскування для отримання необхідного ефекту із можливістю нарощування заходів протидії у разі необхідності (утримання необхідного резерву сил і засобів маскування).

Необхідність дотримання вказаних вимог підтверджуються результатами застосування військ (сил) в Афганістані, Сирії, Нагірному Карабасі. При цьому, складність умов обстановки, яка створюється під час застосування противником ТЗПРНЗ викликає потребу дотримання певних принципів застосування сил і засобів маскування військових об'єктів.

Принципи застосування сил і засобів маскування військових об'єктів як і принципи застосування будь-яких засобів збройної боротьби відображають певні закони та закономірності ведення операцій (бойових дій) та, насамперед, обумовленні факторами, які впливають на їх результат [8].

Основним фактором, який визначає результат вирішення як часткових, так і основних завдань військ (сил) в операціях (бойових діях) є противник. Від складу його сил і засобів, положення, стану, можливостей, характеру дій залежить зміст бойових завдань та обсяг завдань 3 маскування військових об'єктів.

Сьогодні на озброєнні збройних сил країн, що межують 3 Україною, знаходяться досконалі ТЗПРНЗ, які використовують практично весь освоєний на сучасному етапі розвитку науки i техніки діапазон електромагнітних хвиль.

Це положення, а також особливості застосування ТЗПРНЗ противника обумовлюють доцільність обов'язкового урахування під час застосування сил і засобів маскування військових об'єктів таких принципів застосування сил і засобів маскування військових об'єктів:

- постійна готовність військ до маскування військових об'єктів від ТЗПРНЗ противника;

- відповідність організації маскування військових об'єктів від ТЗПРНЗ противника визначеним завданням військ (сил) в операціях (бойових діях);

- організація та здійснення заходів маскування 
військових об'єктів по єдиному замислу захисту військ та об'єктів від ударів ЗПН противника на підставі прийнятого замислу (плану) операції (бойових дій);

- надійність маскування військових об'єктів від ТЗПРНЗ противника;

- безперервність протидії ТЗПРНЗ противника;

- зосередження основних зусиль маскування військових об'єктів від ТЗПРНЗ противника на головному напряму та у визначений час;

- вибіркове застосування сил та засобів маскування для маскування найбільш важливих дійсних військових об'єктів та створення хибних об'єктів;

- тверде управління силами маскування;

- масштабність застосування сил і засобів маскування в операції (бойових діях).

Постійна готовність військ до маскування військових об'єктів від ТЗПРНЗ противника є основним базовим принципом та досягається комплексом організаційних та технічних заходів, спрямованих на підтримання готовності до дій в умовах широкомасштабного застосування противником ЗПН.

Відповідність організації маскування військових об'єктів від ТЗПРНЗ противника визначеним завданням військ (сил) в операціях (бойових діях) обумовлена постійною модернізацією існуючих та створення нових ТЗПРНЗ, що у свою чергу вимагає нових підходів до визначення ефективних способів маскування військових об'єктів для підвищення їх живучості та збереження боєздатності військ (сил).

Організація та здійснення заходів маскування військових об'єктів по єдиному замислу та плану вимагає узгоджувати застосування різноманітних варіантів маскування військових об'єктів від ТЗПРНЗ противника по завданнях, місцю, часу на напрямках дій.

Надійність застосування сил та засобів маскування полягає в зниженні втрат військових об'єктів від ударів ЗПН противника та ймовірності їх виявлення ТЗПРНЗ противника за рахунок комплексування сил і засобів протидії, їх резервування з урахуванням особливостей функціонування військових об'єктів.

Безперервність маскування військових об'єктів буде вимагати здійснення протидії ТЗПРНЗ противника в будь-яких умовах обстановки.

Вибіркове застосування сил та засобів маскування забезпечує розосередження зусиль ТЗПРНЗ противника та сприяє зниженню ефективності ударів ЗПН шляхом застосування більшої кількості сил і засобів маскування та імітації в період найбільш інтенсивних дій противника.
Тверде та безперервне управління силами маскування досягається постійним знанням обстановки та своєчасним прийняттям рішення на застосування сил і засобів маскування військових об'єктів від ТЗПРНЗ противника.

Застосування сил та засобів маскування військових об'єктів дозволяє оперативно та без значних втрат вирішувати широкий спектр завдань щодо захисту військ від ударів ЗПН противника. У сукупності з тим, що сучасні носії ТЗПРНЗ забезпечують ведення розвідки та ураження військових об'єктів на значних відстанях від лінії бойового зіткнення, обумовлює доцільність дотримання принципу масштабності застосування сил і засобів маскування в операціях (бойових діях).

В умовах широкомасштабного застосування ЗПН неможливо прикривати усі військові об'єкти. Тому, у сучасних умовах значно зростає значення нового принципу мінімальної достатності. Під час маскування та імітації необхідно буде здійснювати прив'язку не до військових об'єктів, а до ЗПН, найважливіших напрямів їх дій, завдань, що вирішуються противником в операції (бойових діях). Реалізація вказаного принципу можлива шляхом більш детального прогнозування дій повітряного противника, якісною організацією управління силами і засобами маскування та імітації, створенням розгалуженої мережі автомобільних, залізничних, морських i річкових шляхів та аеродромів для рішучого маневрування військами.

Новий принцип інтероперабельності вимагає забезпечення сил і засобів маскування необхідною інформацією про дії повітряного противника для одночасного виконання визначених завдань на значній кількості військових об'єктів стратегічного, оперативного та тактичного рівнів, створення необхідних умов для організації взаємодії між різнорідними силами i засобами маскування військових об'єктів від технічних засобів повітряної розвідки та наведення зброї противника.

Вимоги щодо досягнення загальних принципів застосування сил і засобів маскування військових об'єктів від ТЗПРНЗ противника наведені у табл. 1.

Удосконалену сукупність принципів застосування сил і засобів маскування військових об'єктів від технічних засобів повітряної розвідки та наведення зброї противника наведено на рис. 1. Зрозуміло, що наведені на рис. 1 принципи є основними, а їх зміст потребує постійного доповнення в залежності від тенденцій подальшого розвитку збройної боротьби. 
Вимоги щодо досягнення загальних принципів застосування сил і засобів маскування військових об'єктів від ТЗПРНЗ противника

\begin{tabular}{|c|c|}
\hline Загальні принципи & Вимоги щодо досягнення загальних принципів \\
\hline $\begin{array}{c}\text { Безперервність протидії } \\
\text { ТЗПРНЗ противника }\end{array}$ & $\begin{array}{l}\text { Вміле маневрування силами та засобами маскування. } \\
\text { Швидке відновленням боєздатності військ, залучених до маскування } \\
\text { військових об’єктів від ТЗПРНЗ противника. } \\
\text { Своєчасне поповнення витрачених технічних засобів маскування. } \\
\text { Створення ефективної системи технічного обслуговування та ремонту } \\
\text { спеціальної техніки маскування. }\end{array}$ \\
\hline $\begin{array}{c}\text { Вибіркове застосування сил } \\
\text { та засобів маскування для } \\
\text { маскування найбільш } \\
\text { важливих дійсних військових } \\
\text { об’єктів та створення хибних } \\
\text { об'єктів }\end{array}$ & $\begin{array}{l}\text { Застосування сил і засобів маскування в суворій відповідності з планом } \\
\text { операції (бойових дій) та визначених завдань командирами (начальника- } \\
\text { ми) щодо захисту військових об'єктів від ЗПН противника. } \\
\text { Застосування більшої кількості сил і засобів маскування в період } \\
\text { найбільш інтенсивних дій технічних засобів повітряної розвідки та наве- } \\
\text { дення зброї противника. }\end{array}$ \\
\hline $\begin{array}{c}\text { Тверде управління силами } \\
\text { та засобами маскування }\end{array}$ & $\begin{array}{l}\text { Постійне знання обстановки, насамперед, можливостей та ймовірного } \\
\text { характеру дій ЗПН (ТЗПРНЗ) противника. } \\
\text { Своєчасне прийняття рішення на застосування сил і засобів маскування } \\
\text { військових об'єктів. } \\
\text { Чітка постановка завдань військам щодо маскування та імітації військо- } \\
\text { вих об'єктів від ТЗПРНЗ противника, підтриманням з ними встановлено- } \\
\text { го зв'язку. }\end{array}$ \\
\hline $\begin{array}{c}\text { Масштабність застосування } \\
\text { сил і засобів маскування та } \\
\text { імітації в операції } \\
\text { (бойових діях) }\end{array}$ & $\begin{array}{l}\text { Наявність ефективних засобів маскування військових об'єктів від } \\
\text { ТЗПРНЗ противника. } \\
\text { Належна підготовка особового складу органів військового управління та } \\
\text { військ до проведення заходів } 3 \text { маскування військових об'єктів від } \\
\text { ТЗПРНЗ противника. } \\
\text { Одночасне проведення заходів маскування на головних та інших напря- } \\
\text { мах дій ЗПН противника. }\end{array}$ \\
\hline Мінімальна достатність & $\begin{array}{l}\text { Здійснення під час планування застосування сил і засобів маскування жо- } \\
\text { рсткої прив'язки не до військових об'єктів, що прикриваються від ударів } \\
\text { ЗПН противника, а до головних сил повітряного противника, найважливі- } \\
\text { ших напрямів його дій, завдань, що вирішуються в операції (бойових діях). } \\
\text { Раціональний розподіл штатних та доданих сил і засобів маскування між } \\
\text { військовими об’єктами з урахуванням їх важливості та завдань, що вирі- } \\
\text { шуються ними. } \\
\text { Застосування на головних напрямах найбільш боєздатних та ефективних } \\
\text { сил і засобів маскування. }\end{array}$ \\
\hline Інтероперабельність & $\begin{array}{l}\text { Інформація про дії ТЗПРНЗ противника доводиться своєчасно в єдиній } \\
\text { розгалуженій мережі оповіщення про дії повітряного противника. } \\
\text { Військові частини та підрозділи, які залучаються до виконання завдань } \\
\text { маскування військових об’єктів від ТЗПРНЗ противника мають відповід- } \\
\text { ні технічні засоби зв’язку та відображення повітряної обстановки, спро- } \\
\text { можні отримувати інформацію про дії ЗПН противника, організовувати } \\
\text { взаємодію з різнорідними силами і засобами маскування військових } \\
\text { об’єктів від ТЗПРНЗ противника. }\end{array}$ \\
\hline
\end{tabular}

Джерело: розроблено автором. 


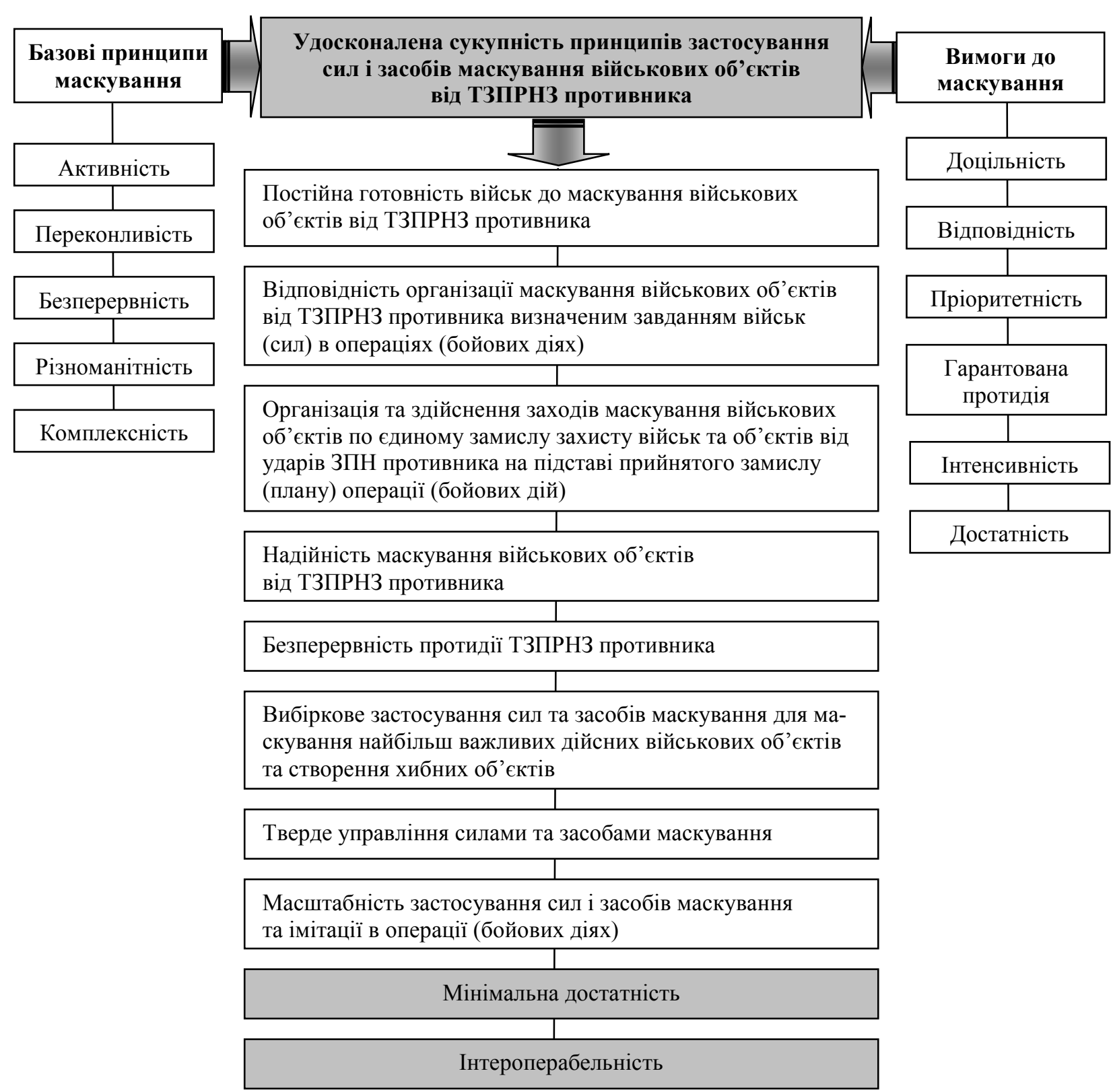

Рис. 1. Удосконалена сукупність принципів застосування сил і засобів маскування військових об'єктів від ТЗПРНЗ противника

Джерело: розроблено автором.

\section{Висновки}

Таким чином, у результаті проведених наукових досліджень набула подальшого розвитку сукупність принципів застосування сил і засобів маскування військових об'єктів від ТЗПРНЗ противника, яка грунтується на базових принципах маскування, вимогах до застосування сил і засобів маскування в операціях (бойових діях), визначених з урахуванням особливостей застосування ТЗПРНЗ в сучасних операціях (бойових діях), та додатково враховує принципи мінімальної достатності та інтероперабельності.

Напрямом подальшого дослідження є розроблення методичного апарату обгрунтування доцільних способів (варіантів) маскування та імітації військових об’єктів від ТЗПРНЗ противника.

\section{Список літератури}

1. Організаційне будівництво Повітряних Сил Збройних Сил України: методичні аспекти / Ю.А. Байдак, О.М. Загорка, В.В. Гамора, В.В. Коваль // Наука і оборона. - 2014. - № 3. - С. 17-22.

2. Застосування аерозольних утворень для захисту військових об'єктів від ударів літаків тактичної авіації/ М.М. Петрушенко, О.М. Загорка, Г.В. Певцов, В.В. Коваль, Г.А. Кучук; за заг. ред. М.М. Петрушенко. - Вінниця-Х.: Командування Повітряних Сил Збройних Сил України; Харківський університет Повітряних Сил імені Івана Кожедуба, 2012. $-128 \mathrm{c}$. 
3. Організація тактичного маскування військ та об'єктів Повітряних Сил Збройних Сил України / О.В. Возний, В.В. Гамора, В.В. Коваль та ін.; за заг. ред. Ю.А. Байдака. - Вінниця: Командування ПС ЗС України, 2015. - 64 с.

4. Організація та здійснення заходів маскування та введення противника в оману в Повітряних Силах Збройних Сил України / В.В. Гамора, В.В. Коваль та ін.; за заг. ред. Ю.А. Байдака. - Вінниця: Командування ПС ЗС України, 2015. $-88 \mathrm{c}$.

5. Методичні рекомендації щодо маскування та імітації військових об'єктів Повітряних Сил Збройних Сил України / О.В. Возний, В.В. Коваль та ін.; за заг. ред. С.С. Дроздова. - Вінниця: Командування ПС ЗС України, 2016. - 64 с.

6. Аерозольна протидія технічним засобам розвідки високоточної зброї противника в бою та операціях / Л.Ф. Кузьменко, О.В. Джежулей, О.С. Ковальов та ін.; за заг. ред. Р.М. Факадея. - К.: НАОУ, 2003. - 136 с.

7. Руководство по инженерным средствам и приемам маскировки Сухопутных войск. Часть І. Средства и приемы маскировки войск. - М.: Воениздат, 1986. -264 с.

8. Методологічні засади обгрунтування раціональних форм та способів застосування угруповань військ (сил): Воєнно-теоретична праця / В.Г. Радецький, І.С. Руснак, О.М. Загорка та ін.; за заг. ред. С.О. Кириченка - К.: НАОУ, 2007. $-288 \mathrm{c}$

Надійшла до редколегії 05.08.2020 Схвалена до друку 22.09.2020

\section{Відомості про автора:}

Коваль Володимир Валерійович кандидат військових наук старший науковий співробітник начальник Воєнно-наукового управління Генерального штабу ЗС України, Київ, Україна https://orcid.org/0000-0002-6209-6779
Information about the author:

Volodymyr Koval

Candidate of Military Sciences Senior Research

Chief of Military Science Division

of General Staff of the Armed Forces of Ukraine,

Kyiv, Ukraine

https://orcid.org/0000-0002-6209-6779

\title{
УСОВЕРШЕНСТВОВАННАЯ СОВОКУПНОСТЬ ПРИНЦИПОВ ПРИМЕНЕНИЯ СИЛ И СРЕДСТВ МАСКИРОВКИ ВОЕННЫХ ОБЪЕКТОВ ОТ ТЕХНИЧЕСКИХ СРЕДСТВ ВОЗДУШНОЙ РАЗВЕДКИ И НАВЕДЕНИЯ ОРУЖИЯ ПРОТИВНИКА
}

\author{
В.В. Коваль
}

Совериенствование возможностей современных технических средств воздушной разведки и наведения оружия (ТСВРНО), новые формы и способы действий воздушного противника обусловливают необходимость существенного повышения эффективности проведения мероприятий маскировки военных объектов. В статье, с учетом особенностей применения ТСВРНО в современных операциях (боевых действиях) определена совокупность принципов применения сил и средств маскировки военных объектов, которая основана на базовых приниипах маскировки, требованиях к применению сил и средств маскировки в операчиях (боевых действиях) и дополнительно учитыввает принципы минимальной достаточности и интероперабельности.

Ключевые слова: технические средства воздушной разведки и наведения оружия, маскировки, приниипь.

\section{IMPROVED COMPLEX OF PRINCIPLES FOR USE \\ OF FORCE AND MEANS OF MILITARY FACILITIES CAMOUFLAGE FROM TECHNICAL MEANS OF AIR RECONNAISSANCE AND GUIDANCE OF ENEMY WEAPONS}

\section{Koval}

Improving the capabilities of modern technical means of air reconnaissance and weapon guidance, new forms and methods of actions of the air enemy necessitate significant increase in the effectiveness of camouflaging military facilities. In the article, taking into account the features of use of technical means of air reconnaissance and weapon guidance in modern operations (combat actions), the complex of principles for the use of forces and means of camouflage of military facilities is determined. It is based on the basic principles of camouflage, requirements for the use of forces and means of camouflage in operations (combat actions) and additionally takes into account the principles of minimum sufficiency and interoperability. It is shown that in modern conditions the value of the principle of minimum sufficiency is significantly increasing. During camouflage and imitation, it will be necessary to bind not to military targets, but to the means of air attack, the main directions of their actions, the tasks solved by the enemy in the operation (combat actions). The implementation of this principle is possible through more detailed forecasting of the actions of air enemy, high-quality organization of control of forces and means of camouflage and imitation, the creation of extensive network of road, rail, sea and river routes and airfields for timely maneuvering by troops. At the same time, the new principle of interoperability requires the provision of forces and means of camouflage with the necessary information about the actions of air enemy for the simultaneous fulfillment of certain tasks at significant number of military facilities of the strategic, operational and tactical levels, the creation of the necessary conditions for organizing interaction between heterogeneous forces and means of camouflaging military facilities from technical means of air reconnaissance and enemy weapon guidance.

Keywords: technical means of air reconnaissance and weapon guidance, camouflage, principles. 